\title{
GROWTH PERFORMANCE OF CATFISH SEEDS (Pangasius sp.) WHICH IS GIVEN AN ANTHILL TUBER EXTRACT
}

\author{
Vera Natalia Simamora ${ }^{1}$, Ricky Djauhari ${ }^{1 *}$, Ivone Christiana ${ }^{1}$ \\ ${ }^{1}$ Aquaculture Study Program, University of Palangka Raya \\ St. Cik Ditiro Number 48, Palangka Raya City, Central Kalimantan Province
}

*Correspondence:

djrickyaku@gmail.com

Received : 2021-12-23

Accepted : 2021-12-24

Keywords :

Anthill Bulbs,

Growth, Pangasius sp.

\begin{abstract}
The use of probiotics, prebiotics and aquaculture synbiotics is widely applied to aquaculture intensification as control agents. Three species of endophytic bacteria were found, namely Bacillus sp. (1), Bacillus sp. (2), and Bacillus pumilus which is associated with anthill plants and can produce antioxidant compounds. This study aims to evaluate the growth performance of catfish fry (Pangasius sp.) given ant nest tuber extract. In this study, ant nest tuber extract was mixed into feed using the coated method in doses of $0 \%(A)$, $1 \%(B)$ and $2 \%(C)$. Fish with an initial body weight of $2.00-$ $3.17 \mathrm{~g}$ were kept in three ponds with a total of 9 nets measuring $1 \times 1 \times 1\left(\mathrm{~m}^{3}\right)$ (30 fish/nets), is 3 nets placed in each pond. Fish were fed treatment with three replications for 30 days. The results of this study are the average final biomass weight of catfish ranging from 8.75 to $22.17 \mathrm{~g}$, in all treatments not significantly different from $\mathrm{K}$. The average value of JKP, RKP, EP, LPH and $\mathrm{Wg}$ obtained on administration of the doses of $1 \%$ and $2 \%$ ant nest tuber extract were not significantly different for $\mathrm{K}$. The highest amylase enzyme activity and feed efficiency were found in the catfish fry group that consumed feed supplementation with $1 \%$ ant nest tuber extract, each of $9.537 \mathrm{IU} / \mathrm{mL}$. and $102.57 \%$ and the least feed consumption, namely $443.33 \mathrm{~g}$. It can be concluded that the best dose of ant nest tuber extract which produces amylase enzyme activity and the highest feed efficiency is found in the catfish fry group that consumes feed supplementation with $1 \%$ ant nest tuber extract.
\end{abstract}

\section{INTRODUCTION}

The level of national fish consumption per capita in Indonesia has reached a level of around $54.49 \mathrm{~kg}$ at the end of 2020 . This data exceeds the projection of fish consumption in the ASEAN region which is estimated to increase from 24.5 million tons in 2015 to 36.9 million tons in 2030 and then reach 47.1 million tonnes by 2050 (Chan et al. 2017). The catfish commodity is one of the economically important fish that is not only superior in terms of quality, including resistance to the environment and disease, survival rate, faster growth, and efficient use of feed. However, this fish also has a large market share and the selling price is 
Journal of Fish Health Vol. 1 (2) - Dec 2021

Andayani et al. (2021)

https://doi.org/10.29303/jfh.v1i2.548

quite high. Currently, Indonesian catfish aquaculture is mostly developed with probiotics, not with antibiotics so that it becomes a healthy and environmentally friendly choice. In addition, catfish are cultivated in ponds with clean groundwater and lower density.

The use of probiotics, prebiotics, and aquaculture synbiotics has been widely applied to aquaculture intensification (Kesarcodi-Watson et al. 2008) as biological control agents is an alternative strategy to reduce antibiotic dependence which has significantly increased antibiotic-resistant pathogenic bacteria (Teuber 2001). The administration of a combination of Saccharomyces cerevisiae and prebiotic mannanoligosaccharides (MOS) was able to improve the value of feed efficiency and the feed conversion ratio of catfish reared in stagnant soil ponds (Djauhari and Monalisa 2019).

Ant nest (Myrmecodia pendans) is one type of epiphytic plant originating from Papua which has been used by some people in Indonesia as a traditional medicine for various diseases such as cancer, coronary heart disease, tumors, gout, hemorrhoids and rheumatism. This is because ant nests contain various kinds of biologically active compounds, including terpenoids/steroids, phenolics (Hertiani et al. 2010), flavonoids, tannins and polyphenols (Soeksmanto et al. 2010). Zhaputri (2016) found three species of endophytic bacteria, namely Bacillus sp. (1), Bacillus sp. (2), and Bacillus pumilus which is associated with ant nests and is able to produce antioxidant compounds with inhibition percentage values of $0.31 \%, 0.15 \%$ and $0.37 \%$, respectively. The results of this study support the suspicion of ant nest tubers as a potential new alternative prebiotic source. Information on the application of ant nest tubers to the aquaculture industry, including catfish cultivation, is still very scarce, both for its effect on improving growth performance and fish health status. The purpose of this study was to evaluate the growth performance of catfish fry (Pangasius sp.) given ant nest tuber extract.

\section{METHODOLOGY}

The research was carried out for 30 days in August-September 2021 at UD. Airwana Raya, Outer Ring Orchid Street, Kereng Bangkirai Village, Sebangau District, Palangka Raya City, Central Kalimantan. The test fish used were catfish fry (Pangasius sp.) with an average weight of 2.00-3.17 g (using Kenko scale model KK-SW1W capacity $30 \mathrm{~kg} \times 1 \mathrm{~g}$ ), adapted for 1 week. This study uses 3 earthen ponds, each installed 3 nets. In pool 1 there are C1, B3 and $A 2$; in pool 2 there are $A 1, B 2$ and $C 2$; and in pool 3 there are $C 3, A 3$ and $B 1$. Net used measuring $(1 \times 1 \times 1) \mathrm{m}^{3}$ with the number of fish stocked as many as 30 fish per net.

$100 \mathrm{~g}$ of ant nest tubers from Pasar Besar in Palangka Raya City, Central Kalimantan, were extracted with distilled water at $100 \mathrm{C}$ with a ratio of 1:10 material and solvent (Marlis 2008) for two hours according to the method of Sittiwet et al. (2009) and Zhong et al. (2007). Preparation of the test feed was carried out by adding $0 \%$ (treatment $A$ ), $1 \%$ (treatment B) and $2 \%$ (treatment C) $(\mathrm{v} / \mathrm{w})$ dose of ant nest tuber extract. Mixing commercial feed with a protein content of $40 \%$ and ant nest tuber extract was carried out by adding ant nest tuber extract to the feed according to the treatment dose. Mixing ant nest tuber extract with artificial feed was carried out by the coating method and $2 \%$ egg white was added as a binder (adhesive). Furthermore, the feed is air-dried for approximately 10 minutes and is ready to be given to the test fish. Feeding during the study was carried out at satiation with a frequency of 2 times a day (08.00 and $16.00 \mathrm{WIB})$. The experimental parameters measured included amylase enzyme activity (Bergmeyer and Grassi 1983), total feed consumption (JKP), 
Journal of Fish Health Vol. 1 (2) - Dec 2021

Andayani et al. (2021)

https://doi.org/10.29303/jfh.v1i2.548

feed conversion ratio (FCR), feed efficiency (EP), daily growth rate (LPH), body weight gain $(\mathrm{Wg})$, and fish survival rate $(\mathrm{TKH})$.

\section{RESULT}

Based on the results of the 30-day study, growth performance data were obtained consisting of survival rate (TKH), total feed consumption (JKP), feed efficiency (EP), feed conversion ratio (RKP), daily growth rate (LPH) and weight gain rate. body (Wg) (Table 1). TKH obtained for the treatment of ant nest tubers in catfish was not significantly different from the control (K). The average final biomass weight of catfish ranged from 8.75 to $22.17 \mathrm{~g}$, in all treatments not significantly different from $\mathrm{K}$. The average value of JKP, RKP, EP, LPH and Wg obtained at the dose of ant nest tuber extract $1 \%$ and $2 \%$ were not significantly different to $\mathrm{K}$ (Table 2). However, supplementation of ant nest tuber extract at a dose of $1 \%$ (treatment $B$ ) showed an average value of the amount of feed consumption, amylase enzyme activity, and feed efficiency of catfish fry that was better than control and treatment C (dose of $2 \%$ ).

Table 1. Initial body weight (Wo), final body weight (Wt), initial biomass (Bo), final biomass $(\mathrm{Bt})$, difference between final and initial biomass $(\triangle \mathrm{B})$, total feed consumption (JKP), feed conversion ratio (FCR), feed efficiency (EP), daily growth rate (LPH), body weight gain $(\mathrm{Wg})$, and survival rate (TKH) of catfish fry given ant nest tuber extract for 30 days of rearing.

\begin{tabular}{|c|c|c|c|c|c|c|c|c|c|c|c|c|c|}
\hline & $\begin{array}{l}\text { Parameters } \\
\text { / } \\
\text { Treatment }\end{array}$ & $\begin{array}{c}\text { wow } \\
\text { (g) }\end{array}$ & $\begin{array}{l}\text { Wt } \\
\text { (g) }\end{array}$ & $\begin{array}{l}\text { Bo } \\
\text { (g) }\end{array}$ & $\begin{array}{l}\text { Bt } \\
\text { (g) }\end{array}$ & $\begin{array}{l}\text { B } \\
\text { (g) }\end{array}$ & $\begin{array}{l}\text { JKP } \\
\text { (g) }\end{array}$ & $\begin{array}{l}\text { Amylase } \\
\text { activity } \\
\text { (IU/mL) }\end{array}$ & FCR & $\begin{array}{l}\text { EP } \\
\text { (\%) }\end{array}$ & $\begin{array}{l}\text { LPH } \\
\text { (\%) }\end{array}$ & $\begin{array}{l}\text { Wg } \\
\text { (\%) }\end{array}$ & $\begin{array}{l}\text { TKH } \\
\text { (\%) }\end{array}$ \\
\hline \multirow[t]{3}{*}{1 pool } & C1 & 2.17 & 8.75 & 65 & 70 & 5 & 390 & 8,761 & - & - & - & - & 26.67 \\
\hline & B3 & 2.17 & 19.66 & 65 & 570 & 505 & 450 & 8.110 & 0.89 & 112.22 & 6.41 & 776.92 & 96.67 \\
\hline & A2 & 2.00 & 17.22 & 60 & 465 & 405 & 410 & 8,646 & 1.01 & 98.78 & 6.03 & 675 & 90 \\
\hline \multirow[t]{3}{*}{2 pool } & A1 & 2.17 & 21.43 & 65 & 600 & 535 & 435 & 7,331 & 0.81 & 122.99 & 6.56 & 823.08 & 93.33 \\
\hline & B2 & 3.17 & 22.17 & 95 & 665 & 570 & 420 & 10,061 & 0.74 & 135.71 & 6.96 & 600 & 100 \\
\hline & C2 & 3.00 & 18.67 & 90 & 560 & 470 & 405 & 7,865 & 0.86 & 116.05 & 6.54 & 522.22 & 100 \\
\hline \multirow[t]{3}{*}{3 pool } & C3 & 2.50 & 17,17 & 75 & 515 & 440 & 505 & 7,051 & 1.15 & 87.13 & 5.65 & 586.67 & 100 \\
\hline & A3 & 2.33 & 16.72 & 70 & 485 & 415 & 485 & 8.805 & 1.17 & 85.57 & 5.68 & 592.86 & 96.67 \\
\hline & B1 & 2.50 & 13.46 & 75 & 350 & 275 & 460 & 10,441 & 1.67 & 59.78 & 4.53 & 366.67 & 86.67 \\
\hline
\end{tabular}

Table 2. Average value of initial biomass (Bo), final biomass ( $\mathrm{Bt}$ ), difference between final and initial biomass $(\triangle B)$, total feed consumption (JKP), feed conversion ratio (FCR), feed efficiency (EP), growth rate daily (LPH), body weight gain $(\mathrm{Wg})$, and survival rate (TKH) of catfish fry given ant nest tuber extract for 30 days of rearing 
Journal of Fish Health Vol. 1 (2) - Dec 2021

Andayani et al. (2021)

https://doi.org/10.29303/jfh.v1i2.548

\begin{tabular}{ccccccccccc}
\hline $\begin{array}{c}\text { Parameter/ } \\
\text { Treatment }\end{array}$ & Bo(g) & Bt(g) & B(g) & JKP (g) & $\begin{array}{c}\text { Amylase } \\
\text { activity } \\
\text { (IU/mL) }\end{array}$ & FCR & EP (\%) & $\begin{array}{c}\text { LPH } \\
(\%)\end{array}$ & $\begin{array}{c}\text { Wg } \\
(\%)\end{array}$ & $\begin{array}{c}\text { TKH } \\
(\%)\end{array}$ \\
\hline A & 65 & 516.67 & 451 & 443.33 & 8,261 & 1.0 & 102.45 & 6.09 & 696.98 & 93.33 \\
B & 78.33 & 528.33 & 450 & 443.33 & 9,537 & 1.1 & 102.57 & 5.97 & 581.2 & 94.45 \\
C & 76.67 & 537.5 & 455 & 455 & 7,892 & 1.0 & 101.59 & 6.1 & 554.45 & 100 \\
\hline
\end{tabular}

\section{DISCUSSION}

The results of this study indicated that supplementation of ant nest tuber extract was thought to increase the population and diversity of amylolytic bacteria in the intestines of the test fish. In general, the activity of the amylase enzyme in the digestive tract of carnivorous fish including catfish is lower than that of omnivorous fish, but is still influenced by the treatment feed (German et al . 2004, 2010). The highest amylase enzyme activity in this study was indicated by the treatment with a dose of $1 \%$ ant nest tuber extract, it is suspected that this value is a combination of endogenous enzyme activity produced by fish naturally and exogenous enzymes produced by amylolytic bacteria. The digestive organs of fish are generally very sensitive to the composition of feed and cause direct changes in the activity of digestive enzymes, which in turn improve the growth performance and health status of fish. Amylase enzyme activity at a dose of $2 \%$ ant nest tubers was thought to reduce some of the amylolytic bacteria in the catfish intestine which caused the amylase enzyme activity to be low, but the amylase and protease enzyme activities were thought to remain normal.

Persistent high production of endogenous glucose regardless of the level of carbohydrate intake may lead to competition between exogenous glucose and endogenous glucose as an energy source, may explain the low utilization of dietary carbohydrates in fish. This shows the ability of the liver specifically hepatocytes to regulate the storage and distribution of glucose. The increase in population and diversity of probiotic bacteria in the intestine is influenced by the dose of prebiotic given, the total number and diversity of bacteria increases with the increase in the dose of prebiotic given. This indicates that the prebiotic dose given is thought to provide a substrate for bacterial growth in the digestive tract so that the population and diversity is higher than the control (Djauhari et al. 2017). Feed efficiency, feed conversion, daily growth rate, and body weight gain were shown to be better in catfish that consumed feed containing ant nest tuber extract with the best yield at a dose of $1 \%$. This was very clearly seen in pond 1 (treatment B3) and pond 2 (treatment B2), the feed efficiency values were $112.22 \%$ and $135.71 \%$, respectively, higher than control and treatment $C$ (dose $2 \%$ ), except in treatment $B 1$ in pond 3 . This means that a $1 \%$ dose of ant nest tuber supplementation can support maximum growth performance with the water quality parameter requirements of the aquaculture environment in the optimum range according to the needs of catfish. As it is known, survival and growth rates are the biological parameters that will determine the success or failure of an aquaculture business, including catfish aquaculture. The results of research Djauhari et al. (2017) obtained the application of a $2 \%$ dose of Sukuh sweet potato extract as a prebiotic, containing three types of prebiotics, namely FOS, GOS, and inulin in carp resulting in better growth performance, immune response, and resistance to infection with Aeromonas hydrophila.

Carbohydrates serve as the main source of energy in cells, are mandatory fuel for the central nervous system and erythrocytes in the simplest form, namely glucose. In addition, carbohydrate metabolism is at the center of all metabolic processes. The utilization of feed 
Journal of Fish Health Vol. 1 (2) - Dec 2021

Andayani et al. (2021)

https://doi.org/10.29303/jfh.v1i2.548

carbohydrates and different digestibility between fish species are thought to be related to different amylase production. The results showed that the average weight of catfish fry at a dose of $1 \%$ ant nest extract treatment was $18.43 \mathrm{~g}$ better than the control treatment and a dose of $2 \%$ although not significantly different, this indicates good glucose tolerance, namely the ability of fish to quickly overcome the glucose load which in turn results in increased growth. The average weight growth of red seabream fish for 30 days fed with a glucose content of $0 \%$ and $10 \%$, respectively, was higher than that of fish fed a glucose content of $30 \%$ and $40 \%$. The amount of feed consumed will affect the growth of fish. The higher the feed consumption, the chance to experience rapid growth is also high. The difference in the amount of feed consumption is thought to be due to differences in fish size due to differences in growth rates during the study. Large fish tend to require or consume more feed than smaller fish. Feed efficiency is related to fish growth rate and feed consumption. The higher the growth rate at the same feed consumption, the higher the feed efficiency. The average feed efficiency was $102.57 \%$ and the amylase enzyme activity averaged $9.537 \mathrm{IU} / \mathrm{ml}$ in fish treated with a dose of $1 \%$ ant nest extract. for the body's protein synthesis which is reflected in the high growth rate of fish. The main determinants of important phenotypes in aquaculture are fast growing, disease resistance, and efficient use of feed. The best growth performance for 30 days of maintenance indicated that supplementation of ant nest tuber extract at a dose of $1 \%$ could improve the amount of feed consumption, the value of amylase enzyme activity, feed efficiency, feed conversion ratio and daily growth rate of catfish. Growth and efficiency in the utilization of feed nutrients are two basic criteria that greatly determine the production, productivity and profitability of an aquaculture industry, including catfish aquaculture.

The improvement in growth performance was caused by the increased activity of digestive enzymes, the improvement of the microvilli structure on the surface of the enterocytes which made the surface of the nutrient-absorbing cells wider so that the feed efficiency increased, as well as the production of short chain fatty acids (SCFA) because of prebiotic fermentation by the intestinal endocellular microflora. MOS supplementation at a dose of $0.2 \%$ increased the microvilli length of cobia (Rachycentron canadum) larvae (Salze et al. 2008) and increased the density of the fore and hind gut microvilli of gilthead sea bream (Sparus aurata) (Dimitroglou et al. 2010). Oligosaccharides are also able to improve intestinal morphology along with the potential to control oxidative stress, thereby increasing the efficiency of intestinal absorption capacity through the mechanism of expanding the intestinal microvilli area, which has a positive impact on growth (Solis de los Santos et al. 2005; Song et al. 2010).

Supplementation of ant nest tubers is thought to be able to modify the presence of probiotics in the digestive tract which can increase the enzyme activity of the catfish digestive tract. Amylase, protease, and lipase enzymes produced by probiotics can contribute to the activity of endogenous fish enzymes so that fish that consume feed containing prebiotics indirectly have higher digestive enzyme activity than controls. The increase in enzyme activity can then help improve feed digestibility. Probiotics are able to help the digestive process as evidenced by better fish growth because they produce various kinds of extracellular enzymes, including amylase, protease and lipase so that feed digestion and nutrient utilization becomes more efficient (Djauhari et al. 2017). The protease enzymes produced by probiotics function to help break down peptide bonds in proteins, then break down in detail into protein core elements in the form of monomers and free amino acids, which are very useful for improving the nutritional status of fish. Probiotic bacteria are also able to produce lipase enzymes that trigger the production and assimilation of essential fatty acids, resulting in higher growth and 
Journal of Fish Health Vol. 1 (2) - Dec 2021

Andayani et al. (2021)

https://doi.org/10.29303/jfh.v1i2.548

immunity of pomfret. Essential fatty acids are not only a booster for the immune system, but also stimulate growth (Sharma et al. 2009). Bacterial enzymatic hydrolysis resulted in an increase in catfish growth and was supported by a low FCR value, indicating an increased bioavailability of protein and fat. According to Djauhari et al. (2017), amylase and lipase are the main enzymes associated with the breakdown of carbohydrates and fats. Amylase, protease and lipase activity was higher in fish fed prebiotic-containing feed than control. The activity of amylase, protease and lipase enzymes in prebiotic treatment was partly the result of stimulation by probiotics, and together with endoenzymes synergized to improve digestibility efficiency and nutrient utilization, resulting in good growth performance and feed conversion ratio.

The survival rate of catfish reaches $100 \%$ for 30 days of catfish rearing treated with $2 \%$ ant nest tuber extract (treatment $\mathrm{C}$ ) allegedly due to the potential reason for this material as a prebiotic and herbal to provide tolerance and resistance effects to environmental stressors and pathogen invasion. So that the catfish in this treatment group showed a fitter body metabolism. As an exception in the $\mathrm{C} 1$ treatment, catfish mortality reached $73.33 \%$ due to the presence of snakehead fish predators that entered the hapa net, this was possible when it rained. Several types of prebiotics can stimulate and modulate the response of dendritic cells to LPS (lipopolysaccharide) pathogens (Wismar et al. 2010). The indirect effect of prebiotics on the immune system response begins with the stimulation of the growth of probiotic bacteria in the host intestine and/or stimulation of the production of SCFA (short chain fatty acids). Increasing the optimal number of beneficial bacteria has the potential to stimulate mucus production, positive regulation of genes involved in the formation of communication networks between epithelial cells, and stimulation of immune cells. SCFA stimulates the growth and differentiation of epithelial cells, regulates the formation of communication networks between epithelial cells, and regulates pro-inflammatory immune cells. Some prebiotics have a direct mechanism of action on enterocytes and intestinal mucocytic cells by binding to specific receptors, leading to increased intestinal permeability and barrier integrity and reduced risk of translocation of pathogens from the host gut. Increasing the optimal number of probiotic bacteria has been proven to provide immune system booster and protective effect against pathogen invasion.

\section{CONCLUSION}

The best dose of ant nest tuber extract which produced amylase enzyme activity and the highest feed efficiency was found in the catfish fry group that consumed feed supplementation with $1 \%$ ant nest tuber extract, $9.537 \mathrm{IU} / \mathrm{mL}$ and $102.57 \%$ respectively, as well as feed consumption. least, that is $443.33 \mathrm{~g}$.

\section{ACKNOWLEDGMENT}

The authors thank the University of Palangka Raya for accommodating and facilitating this research.

\section{REFERENCES}

Bergmeyer HU, Grassi M, (1983). Methods of Enzymatic Analysis. 2. Weinheim: Verlag Chemie. 
Journal of Fish Health Vol. 1 (2) - Dec 2021

Andayani et al. (2021)

https://doi.org/10.29303/jfh.v1i2.548

Chan CY, Tran N, Dao CD, Sulser TB, Phillips MJ, Batka M, Wiebe K, Preston N. (2017). Fish to 2050 in the ASEAN region [Working Paper]. WorldFish. Penang. International Food Policy Research Institute (IFPRI).

Dimitroglou A, Merrifield DL, Spring P, Sweetman J, Moate R, Davies SJ. (2010). Effects of mannan oligosaccharide (MOS) supplementation on growth performance, feed utilization, intestinal histology and gut microbiota of gilthead sea bream ( Sparus aurata ). Aquaculture $300,182-188$.

Djauhari R, Monalisa SS. (2019). Growth performance of Pangasius sp. catfish . treated with synbiotics in stagnant soil ponds, Bukit Tunggal, Palangka Raya. Journal of Tropical Animal Science, 8 (1), 1-8.

Djauhari R, Widanarni, Sukenda, Suprayudi MA, Zairin M. (2017). Growth performance and health status of common carp (Cyprinus carpio) supplemented with prebitoic from sweet potato (Ipomoea batatas L.) extract.Pakistan Journal of Nutrition. 16, 155-163.

German DP, Horn MH, Gawlicka A. (2004). Digestive enzyme activities in herbivorous and carnivorous prickleback fishes (Teleostei: Stichaeidae): ontogenetic, dietary, and phylogenetic effects. Physiol. biochem. Zool, 77, 789-804.

German DP, Nagle BC, Villeda JM, Ruiz AM, Thomson AW, Contreras-Balderas S, Evans DH. (2010). Evolution of herbivory in a carnivorous clade of minnows (Teleostei: Cyprinidae): effect on gut size and digestive physiology. Physiol. biochem. Zool, 83, 1-18.

Hertiani T, Sasmito E, Sumardi, Ulfah M. (2010). Preliminary study on immunomodulatory effect of tubers Myrmecodia tuberosa and Myrmecodia pendens . J Biological Science 10 (3), 136-41.

Huisman EA. (1987). The Principles of Fish Culture Production. Netherland (NL): Wageningen Agricultural University.

Kesarcodi-Watson A, Kaspar H, Josie Lategan M, Gibson L. (2008). Probiotics in aquaculture: the need, principles and mechanisms of action and screening processes. Aquaculture, $274,1-8$.

Kumar S, Dhankhar S, Arya VP, Yadav S, Yadav JP. (2012). Antimicrobial activity of Salvadora oleoides Decne against some microorganisms. Journal of Medicinal Plants Research, 6, 2,754-2,760.

Marlis A. (2008). Isolation of sweet potato oligosaccharides (Ipomoea batatas L.) and the effect of management on its prebiotic potential [thesis]. Bogor: Bogor Agricultural Univ.

son of AN. (2014). Sweet Potato Varieties Sukuh Potential As A Prebiotics In Tilapia Feed (Oreochromis niloticus). International Conference of Aquaculture Indonesia, 35, 254-258.

Ringo E, Olsen RE, Gifstand TO, Dalmo RA, Amlund H, Hemre GI. (2010). Prebiotics in aquaculture: a review. AquacultNutr ,169, 117-136.

Roberfroid, MB (2000). Prebiotics and Probiotics: Are They Functional Food 1-3. The American Journal of Clinical Nutrition, 71 , 1682S-1687S.

Salze G, McLean E, Schwarz MH, Craig SR. (2008). Dietary mannan oligosaccharide enhances salinity tolerance and gut development of larval cobia. Aquaculture 274, 148-152.

Schrezenmeir J and Vrese M. (2001). Probiotics, Prebiotics and Symbiotics Approaching a Definition. American Journal of Clinical Nutrition, 73 (2), 361-364. 
Journal of Fish Health Vol. 1 (2) - Dec 2021

Andayani et al. (2021)

https://doi.org/10.29303/jfh.v1i2.548

Sharma P, Kumar V, Sinha AK, Ranjan J, Kithsiri HMP, Venkateshwarlu G. (2009). Comparative fatty acid profiles of wild and farmed tropical freshwater fish rohu (Labeo rohita ). Fish Physiol Biochem , 5, 229-239.

Sittiwet C, Niamsa N, Puangpronpitag D. (2009). Antimicrobial activity of Acanthus ebracteatus Vahl. Aqueous extract: The Potential for Skin Infection Treatment. Int J Biol Chem, 3 , 95-98.

Soeksmanto A, Simanjuntak T, Subroto M. (2010). Acute toxicity test of the aqueous extract of the ant nest plant ( Myrmecodia pendans ) on the histology of the liver of mice. $J$ Natur Indo, 12(2), 152-5.

Solis de los Santos F, Farnell MB, Téllez G, Balog JM, Anthony NB, Torres Rodriguez A, Higgins $S$, Hargis BM, Donoghue AM. (2005). Effect of prebiotic on gut development and ascites incidence of broilers reared in a hypoxic environment. Poultry Science, 84 , 1092-1100.

Song X, Xu J, Wang T, Liu F (2010). Traditional Chinese medicine decoction enhances growth performance and intestinal glucose absorption in heat stressed pigs by upregulating the expressions of SGLT1 and GLUT2 mRNA. Livestock Science, 128 (13), $75-81$.

Teuber M. (2001). Veterinary use and antibiotic resistance. Curr. Opinion. Microbiol, 4, 493499.

Watanabe T. (1988). Fish Nutrition and Mariculture. JICA Text Book THE General Aquaculture Course. Tokyo (JP): Department of Aquatic Bioscience, Tokyo University.

Wismar R, Brix S, Laerke HN, Frokiaer H. (2010). Comparative analysis of a large panel of nonstarch polysaccharides reveals structures with selective regulatory properties in dendritic cells. Molecular Nutrition \& Food Research .

Zhaputri RA. (2016). The Potential of Ants Nest Plant Endophytic Bacteria (Myrmecodia pendens) As Antioxidant Producing. Essay. Faculty of Science and Technology, UIN Alauddin Makassar. Makassar.

Zhong HU, Yi-Rui WU, Bao-Rong LI, Hai-Dong W. (2007). Study on Extraction and Physiological of Flavonoids from Acanthus ilicifolius.J of Shantou Univ (Natural Science edition), 03-09. 